\title{
A new species of "sangre de drago" (Croton section Cyclostigma, Euphorbiaceae) from coastal Ecuador
}

\author{
Author(s): Ricarda Riina, Paul E. Berry, Xavier Cornejo \\ Source: Brittonia, 59(1):97-101. \\ Published By: The New York Botanical Garden \\ https://doi.org/10.1663/0007-196X(2007)59[97:ANSOSD]2.0.CO;2 \\ URL: http://www.bioone.org/doi/full/10.1663/0007-196X \\ $\% 282007 \% 2959 \% 5 \mathrm{~B} 97 \% 3 \mathrm{AANSOSD} \% 5 \mathrm{D} 2.0 . \mathrm{CO} \% 3 \mathrm{~B} 2$
}

BioOne (www.bioone.org) is a nonprofit, online aggregation of core research in the biological, ecological, and environmental sciences. BioOne provides a sustainable online platform for over 170 journals and books published by nonprofit societies, associations, museums, institutions, and presses.

Your use of this PDF, the BioOne Web site, and all posted and associated content indicates your acceptance of BioOne's Terms of Use, available at www.bioone.org/page/ terms of use.

Usage of BioOne content is strictly limited to personal, educational, and non-commercial use. Commercial inquiries or rights and permissions requests should be directed to the individual publisher as copyright holder. 


\title{
A new species of "sangre de drago" (Croton section Cyclostigma, Euphorbiaceae) from coastal Ecuador
}

\author{
Ricarda RiInA ${ }^{1, *}$, PAul E. Berry ${ }^{2}$, ANd Xavier Cornejo ${ }^{3}$ \\ ${ }^{1}$ Department of Botany, University of Wisconsin, 430 Lincoln Drive, Madison, Wisconsin 53706, \\ U.S.A.; e-mail: riina@umich.edu \\ ${ }^{2}$ Department of Ecology and Evolutionary Biology, The University of Michigan, 2019 Kraus Nat- \\ ural Science Building, 830 North University Avenue, Ann Arbor, MI 48109-1048, U.S.A.; e-mail: \\ peberry@umich.edu) \\ ${ }^{3}$ Herbario GUAY, Universidad de Guayaquil, Av. 25 de Julio vía al Puerto Marítimo, Casilla 09- \\ 01-10634, Guayaquil, Ecuador; e-mail: xcornejoguay@ hotmail.com \\ ${ }^{*}$ Corresponding author
}

\begin{abstract}
Croton churutensis is described as a new species of Croton section $C y$ clostigma endemic to lowland deciduous forests in coastal Ecuador. Its red latex is used locally in Guayas Province to treat wounds, stomach ulcers, and some skin conditions caused by fungal infections. The new species differs from its closest apparent relative, Croton hibiscifolius, in its arching-pendent inflorescences, short-pedicellate female flowers with quadrifid stigmas, more numerous stamens, laciniate stipules, and lower elevation habitat.
\end{abstract}

Key words: Croton churutensis, sangre de drago, Euphorbiaceae, Ecuador, Guayas, Loja.

Croton (Euphorbiaceae s.s.) is a genus of over 1220 currently recognized species (Govaerts et al., 2000). In Webster's (1993) sectional synopsis of the genus, he recognized section Cyclostigma as a group of about 50 species from both the New and Old Worlds, defined by a suite of characters including a mainly arborescent to shrubby habit, stellate to stellate-lepidote indumentum, reddish trunk sap, glandular petiole apices, bisexual basal cymules of the infloresence, and pedicellate pistillate flowers. Smith (2002) studied the Ecuadorian members of the section and recognized 11 species native to Ecuador. The first molecular study of the genus (Berry et al., 2005) sampled ten species in section Cyclostigma sensu Webster and concluded that the section is polyphyletic, with a core Cyclostigma group confined to Central and South America and characterized by arborescent habit and viscous, reddish sap known locally as "sangre de drago," or dragon's blood. These species are widely used by local inhabitants for the treatment of diarrhea, cuts, stomach ulcers, herpes infection, and the itching and swelling of insect bites (Meza \& Pariona, 1999; Jones, 2003). In 2003, the senior author visited major herbaria in Ecuador and in several collections found material of an undescribed member of the section. The new species is described below, and occurs in seasonally dry areas in coastal Ecuador or somewhat inland at low elevations, unlike most species of section $\mathrm{Cy}$ clostigma that are restricted to moist, montane habitats.

Croton churutensis R. Riina \& X. Cornejo, sp. nov. Type: Ecuador. Guayas: Reserva Ecológica Andrade, km 43 vía GuayaquilMachala, bosque seco tropical, $79^{\circ} 40^{\prime} \mathrm{W}$, $2^{\circ} 24 ' \mathrm{~S}, 20 \mathrm{~m}, 25$ Jan 2003, X. Cornejo \& C. Bonifaz 7590 (holotype GUAY; isotypes DAV, QCA, QCNE, WIS).

(Fig. 1)

Croton hibiscifolio Kunth affinis sed inflorescentiis pendentibus, stigmatibus quadrifidis, floribus foemineis breviter pedicellatis, staminibus ca. 24 , stipulis ovatolaciniatis differt. 


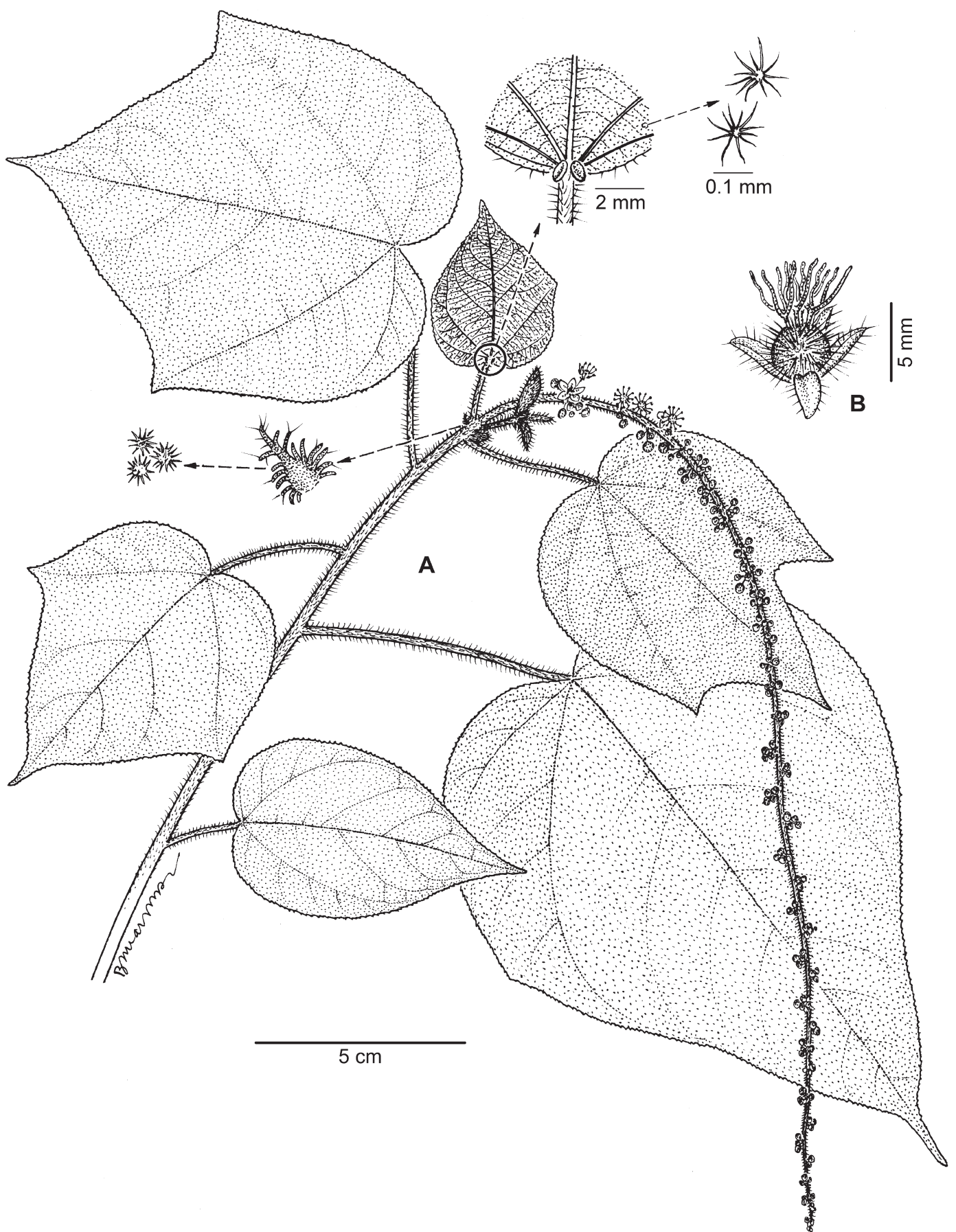

Fig. 1. Croton churutensis. A. Flowering branch showing details of stipules and petiolar glands. B. Pistillate flower. (From Cornejo \& Bonifaz 7590, WIS). 
Tree 3-8 m high, ca. $20 \mathrm{~cm} \mathrm{DBH}$; young branches covered with dense whitish to golden yellow indumentum of stellate-porrect trichomes with central porrect rays $1.5-2 \mathrm{~mm}$ long; upper surface of foliage dark green, lower surface pale green; latex from the stem and young branches dark red. Stipules ovatelanceolate, 3-6 mm long, 1-3 $\mathrm{mm}$ wide, persistent on young branches, margins conspicuously laciniate, with 12-16 nonglandular laciniae. Leaves alternate, membranaceous to papery (when dry), with a pleasant smell when fresh leaves are rubbed; leaf blade unlobed or with 2 or 3 acute to acuminate lobes in the upper third of the blade, 5-15(-20) $\times 3-14(-$ 16) $\mathrm{cm}$; apex sharply-acute to caudateacuminate; base usually cordate or less commonly truncate; margin minutely denticulate with numerous ovoid glands; venation actinodromous, palminerved with 3-5 veins from base and 5-8 lateral veins per side of midrib further up the lamina, tertiary veins scalariform, weakly sinuous, the primary and secondary veins raised on the abaxial surface; foliar glands 2, acropetiolar, attached to the petiole on the abaxial surface, discoid, elliptic, $0.7-1 \mathrm{~mm}$ in diam., glandular surface lustrous and yellow in life, sessile to shortly stipitate; petioles $1.5-10 \mathrm{~cm}$ long, with dense indumentum of stellate-porrect trichomes, rays $0.08-$ $0.10 \mathrm{~mm}$ long, central porrect ray $1-1.5 \mathrm{~mm}$ long; adaxial leaf indumentum sparse, trichomes stellate-porrect, denser along the veins; abaxial leaf surface with denser indumentum of stellate-porrect trichomes, those along the veins with longer porrect central rays. Inflorescences terminal, arching-pendent, $5.5-30 \mathrm{~cm}$ long; upper cymules with $3-5$ flowers, rachis angular, golden brown with dense covering of stellate-porrect trichomes, lower cymules bisexual with 3-8 staminate flowers and 1 or 2 pistillate flowers; pistillate bracts widely triangular, ca. $2 \times 1 \mathrm{~mm}$; staminate bracts linear, $1-1.2 \times 0.2-0.4 \mathrm{~mm}$. Staminate flowers distributed along the inflorescence from base to top; pedicels 4-6 $\mathrm{mm}$ long; sepals 5 , valvate, ovate, acute, $2-3 \times 1.5-$ $2.5 \mathrm{~mm}$, adaxial surface glabrous, abaxial surface with a dense indumentum of rosulate and/or multiradiate porrect trichomes; petals 5, oblong to oblong-lanceolate, creamcolored, $2-3 \times 1-1.2 \mathrm{~mm}$, the adaxial surface glabrous except for a cluster of long hairs at

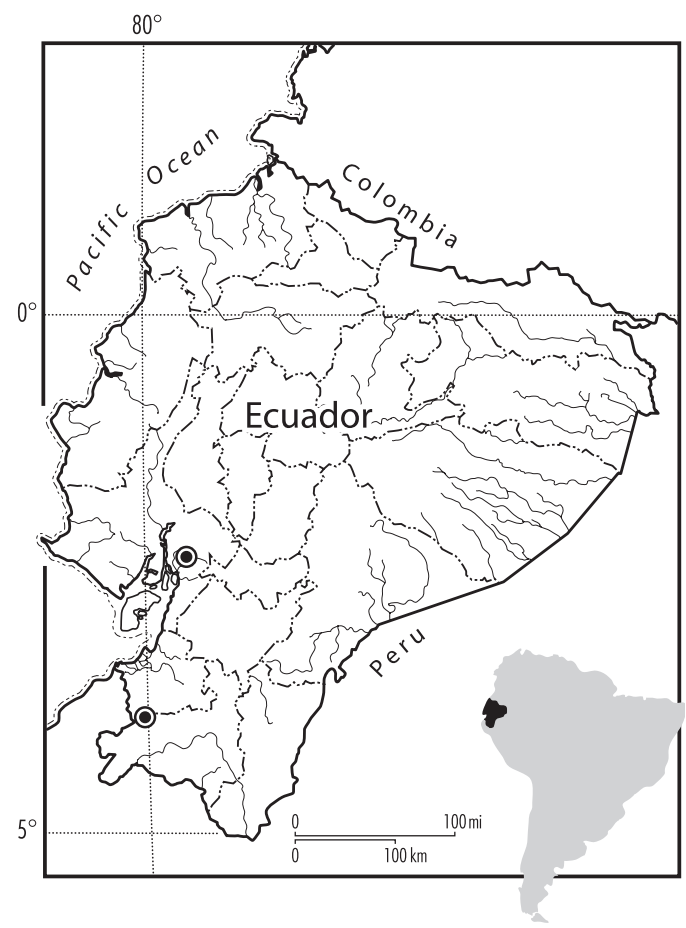

Fig. 2. Geographical distribution of Croton churutensis.

the base, abaxial surface sparsely pilose, edges lanate; receptacle densely pilose; stamens ca. 24; filaments $2-3 \mathrm{~mm}$ long, glabrous, inflexed in bud; anthers $0.8 \times 0.3-0.4 \mathrm{~mm}$. Pistillate flowers subsessile or short-pedicellate, pedicels $0.5-1.5 \mathrm{~mm}$ long; sepals 5 , valvate, broadly lanceolate to oblong, somewhat unequal, $2.4-3 \times 1-1.5 \mathrm{~mm}$, apex acute, adaxial surface densely pilose toward the edges, abaxial surface densely covered with multiradiate, tall stellate-porrect trichomes; malformed petals generally present, more rarely a stalked or sessile gland present in the same position; ovary $3 \times 2.5 \mathrm{~mm}$, covered with golden-yellow multiradiate and tall stellate-porrect trichomes; styles quadrifid, with 12 (-14) stigmas, the nonreceptive surfaces covered with sparse stellate trichomes. Mature fruits and seeds unknown.

Distribution and habitat. Coastal Ecuador, known mainly from Guayas Province in deciduous forests on sedimentary, basic, and/or well drained rocky soils, from sea level to $700 \mathrm{~m}$ elevation; also known from one location along the coast in Loja Province (Fig. 2). 
TABLE I

Principal Differences that Distinguish Croton churutensis From C. hibiscifolius

\begin{tabular}{lll}
\hline \hline \multicolumn{1}{c}{ Character } & \multicolumn{1}{c}{ C. churutensis } & \multicolumn{1}{c}{ C. hibiscifolius } \\
\hline $\begin{array}{l}\text { Trichomes on young branches } \\
\text { Stipules }\end{array}$ & $\begin{array}{l}\text { Stellate-porrect } \\
\text { Ovate-lanceolate; margins } \\
\text { laciniate, with 12-16 laciniae } \\
\text { Arching-pendent }\end{array}$ & $\begin{array}{l}\text { Stipitate-rosulate, tall dendritic } \\
\text { Lanceolate to linear, entire }\end{array}$ \\
$\begin{array}{l}\text { Inflorescences } \\
\text { Stamens }\end{array}$ & ca. 24 & Erect \\
$\begin{array}{l}\text { Length of pedicel of } \\
\text { pistillate flowers }\end{array}$ & $0.5-1.5 \mathrm{~mm}$ & $15-21$ \\
$\begin{array}{l}\text { Styles } \\
\text { Altitudinal range in Ecuador }\end{array}$ & $\begin{array}{l}\text { Quadrifid } \\
0-700 \mathrm{~m}\end{array}$ & $2-10 \mathrm{~mm}$ \\
\hline
\end{tabular}

Etymology. The specific epithet refers to one of the ecological reserves where the species is found, in the Reserva Ecológica Manglares de Churute ("REMCH"), located in the Churute hills area of Guayas Province in coastal Ecuador.

Uses and common names. The red latex of Croton churutensis is used locally in Guayas Province to treat wounds, stomach ulcers, and some skin conditions caused by fungal infections. Local common names of the species are "Chalá grande" and "Sangre de drago."

Additional specimens examined. Ecuador. GUAYAS: cantón Naranjal, parroquia Taura, $2^{\circ} 27^{\prime} \mathrm{S}$, $79^{\circ} 40^{\prime} \mathrm{W}, 700 \mathrm{~m}$ (MO, WIS) \& 6-200 m (QAP), $31 \mathrm{Dec}$ 1991, Cerón 17917 (MO, QAP, WIS); base del cerro Perequetre Grande, de frente a la Laguna del Canclón, $2^{\circ} 27^{\prime} \mathrm{S}, 7^{\circ} 40^{\prime} \mathrm{W}, 150-200 \mathrm{~m}, 2$ Oct 1992, Cerón et al. 20617 (QAP); Reserva Ecológica Manglares Churute [REMCH], cumbre del cerro Perequetre Grande, $2^{\circ} 27 ' \mathrm{~S}$, 7940'W, 340-370 m, 17 Aug 1992, Cerón et al. 20327 (QAP); REMCH, cumbre del cerro Gallo, $2^{\circ} 27$ 'S, 7940'W, 250-270, 29 Sep 1992, Cerón et al. 20482 (QAP); REMCH, sendero a cerro Mate, $2^{\circ} 27^{\prime} \mathrm{S}, 79^{\circ} 40^{\prime} \mathrm{W}$ 50-350 m, 27 Dec 1991, Cerón et al. 17782 (QAP); $\mathrm{REMCH}$, base del cerro Masvale, $2^{\circ} 27^{\prime} \mathrm{S}, 79^{\circ} 40^{\prime} \mathrm{W}$, 50 m, 30 Sep 1992, Cerón et al. 20518 (QAP); REMCH, $79^{\circ} 38^{\prime} \mathrm{W}, 2^{\circ} 26^{\prime} \mathrm{S}, 300 \mathrm{~m}, 5$ Jan 1994, Cornejo \& Bonifaz 1131 (GUAY, QCNE 2 sheets); Reserva Ecológica Andrade, $\mathrm{km} 43$ vía Guayaquil-Machala, $79^{\circ} 40^{\prime} \mathrm{W}, 2^{\circ} 24^{\prime} \mathrm{S}$, $20 \mathrm{~m}, 25$ Jan 2003, Cornejo \& Bonifaz 7593 (GUAY, QCA, QCNE, WIS); REMCH, Milagro, carretera Guayaquil-Puerto Inca, Sector Norte del Cerro Masvale, 02²0'S, 2950'W, 200-300 m, May 1993, Núñez \& Hernández 148 (QCNE, MO). LoJA: Bosque Petrificado Puyango, quebrada El Limón, $80^{\circ} 02^{\prime} \mathrm{W}, 3^{\circ} 52^{\prime} \mathrm{S}, 350 \mathrm{~m}$, 20 Jun 1995, Cornejo \& Bonifaz 4181 (GUAY).

Nuclear ITS and plastid trnL-trnF intron and spacer DNA sequence data from Cornejo \& Bonifaz 7590 (Riina, in prep.) places Cro- ton churutensis within the core Cyclostigma clade identified by Berry et al. (2005), but its close sister species within that clade have not yet been resolved. In several of the Ecuadorian herbaria and in previous floristic publications such as Cerón (1996), C. churutensis was treated as $C$. gossypiifolius Vahl. However, that species does not occur in Ecuador and is native to Trinidad and northern Venezuela and Colombia (Smith, 2002). A close relative of $C$. gossypiifolius that occurs in north-central Ecuador and in Colombia and western Venezuela is C. hibiscifolius Kunth. According to Smith (2002), most of the other specimens that have been identified as $C$. gossypiifolius in Ecuador are actually $C$. hibiscifolius. The leaves of $C$. churutensis are similar to those of $C$. hibiscifolius, but the species differ in several other morphological and ecological features that are summarized in Table I. Croton churutensis resembles another species of section Cyclostigma from eastern Bolivia, C. charaguensis Standl., in having entire to lobate leaves with basal ovoid glands, minutely denticulate leaf margins, laciniate stipules, quadrifid stigmas, a small tree habit, and a similar habitat in deciduous forests. However, C. charaguensis differs from $C$. churutensis in its much shorter inflorescences, four to six long-stipitate petiolar glands, and more numerous stamens (40 or more).

\section{Acknowledgments}

We wish to thank the Ecuadorian herbaria GUAY, QAP, and QCNE for access to their collections. Bruno Manara (VEN) provided 
the line drawing of the new species, and Kandis Elliot (WIS) assisted with the preparation of the map and formatting of the illustration. We also thank Homero Vargas, Rosa Miranda, and Carlos Cerón for their invaluable support and assistance to R. Riina during her visit to Ecuador, and Kenneth Wurdack and another anonymous reviewer for their constructive review comments. This paper was partially funded by U.S. National Science Foundation (award \# DEB-0212481 to PEB) and by a travel grant from the University of Wisconsin Latin American, Iberian, and Caribbean Studies Program (LACIS) to RR.

\section{Literature Cited}

Berry, P. E., A. L. Hipp, K. J. Wurdack, B. Van Ee \& R. Riina. 2005. Molecular phylogenetics of the giant genus Croton and tribe Crotoneae (Euphorbiaceae sensu stricto) using ITS and trnL-trnF DNA sequence data. American Journal of Botany 92(9): 1520-1534.
Cerón, C. E. 1996. Diversidad, especies vegetales y usos en la Reserva Ecológica Manglares-Churute, Provincia del Guayas-Ecuador. Revista Geográfica No. 36. Instituto Geográfico Militar Quito, Ecuador.

Govaerts, R., D. G. Frodin \& A. Radcliffe-Smith. 2000. World checklist and bibliography of Euphorbiaceae and Pandaceae. 4 vols. Royal Botanic Gardens, Kew, England.

Jones, K. 2003. Review of Sangre de Drago (Croton lechleri) -A South American Tree Sap in the Treatment of Diarrhea, Inflammation, Insect Bites, Viral Infections, and Wounds: Traditional Uses to Clinical Research. The Journal of Alternative and Complementary Medicine 9: 877-896.

Meza, E. N. \& M. Pariona.1999. Nombres aborígenes peruanos de las especies de Croton que producen el látex denominado "Sangre de Drago". Pp. 25-44. In: E. N Meza, (ed.), Desarrollando nuestra diversidad biocultural: "Sangre de drago" y el reto de su producción sustentable en el Perú. Universidad Mayor de San Marcos, Fondo Editorial, Lima.

Smith, B. A. 2002. A systematic revision of Croton section Cyclostigma (Euphorbiaceae) in Ecuador. Ph.D. thesis, University of California-Davis.

Webster, G. L. 1993. A provisional synopsis of the sections of the genus Croton (Euphorbiaceae). Taxon 42: 793-823. 